\title{
THE CONTRIBUTION OF ABILITY TO WORK AND ACHIEVEMENT MOTIVATION ON THE PERFORMANCE OF SCHOOL ADMINISTRATION HEAD OF PUBLIC JUNIOR HIGH SCHOOLS IN BANDUNG
}

\author{
KONTRIBUSI KEMAMPUAN KERJA DAN MOTIVASI BERPRESTASI TERHADAP \\ KINERJA KEPALA TATA USAHA SMP NEGERI \\ DI KOTA BANDUNG
}

\author{
Yudi Ekka Suryapriadi \\ yudi upi@yahoo.com \\ Staf Pengajar Universitas Pendidikan Indonesia
}

\begin{abstract}
School effectiveness is influenced by many factors, one of this is the quality of School Administration Head in providing administrative services in education. With excellent administration services, learning activities will run conducively. Therefore, this study will examine how the ability to work and achievement motivation on the performance of School Administration Head of Public Junior High Schools in Bandung. The research method used is quantitative method. The data obtained from 30 school headmasters as primary data and 30 Heads of Administrations as secondary data. According to the analysis results using statistic program there are some results as follows : (1) The work performance of the school administration head of Public Junior High Schools in Bandung exist in high category; (2) The Achievement Motivation of the school administration head of Public Junior High School in Bandung exist in High Category; (3) The Performance of the School Administration Head of Public Junior High Schools in Bandung exist in High Category; (4) There is a positive and significant contribution between the ability to work to the performance of school administration head in the public Junior High School in Bandung with strong category; (5) There is a positive and significant contribution between achievement motivation to the performance of School Administration Head of Public Junior High School with strong category; (6) There is a positive and significant contribution between the ability to work and achievement motivation to the performance of school administration head in the Public Junior High Schools in Bandung with strong category.
\end{abstract}

Key Words : Ability to Work, Achievement Motivation, Performance

Efektivitas sekolah dipengaruhi oleh banyak faktor, salah satunya adalah kualitas Kepala Tata Usaha Sekolah dalam memberikan layanan administrasi pendidikan. Dengan layanan administrasi yang baik, kegiatan belajar mengajar akan berjalan secara kondusif. Karena itu, penelitian ini akan mengkaji tentang bagaimana kontribusi kemampuan kerja dan motivasi berprestasi terhadap kinerja Kepala Tata Usaha SMP Negeri di Kota Bandung. Metode penelitian menggunakan metode kuantitatif. Data diperoleh dari 30 orang Kepala Sekolah sebagai data Primer dan 30 orang Kepala Tata Usaha sebagai data sekunder. Berdasarkan hasil analisis data dengan bantuan statistik diperoleh hasil penelitian sebagai berikut: (1) Kemampuan kerja Kepala Tata Usaha SMP Negeri di Kota Bandung berada pada kategori tinggi; (2) Motivasi berprestasi Kepala SMP Negeri di Kota Bandung berada pada kategori tinggi; (3) Kinerja Kepala Tata Usaha SMP Negeri di Kota Bandung berada pada kategori tinggi; (4) Terdapat kontribusi positif dan signifikan antara kemampuan kerja terhadap kinerja Kepala Tata Usaha SMP Negeri di Kota Bandung dengan kategori kuat; (5) Terdapat kontribusi yang positif dan signifikan antara motivasi berprestasi terhadap kinerja Kepala Tata Usaha SMP Negeri di Kota Bandung dengan kategori kuat; dan (6) Terdapat kontribusi positif dan signifikan antara kemampuan kerja dan motivasi berprestasi terhadap kinerja Kepala Tata Usaha SMP Negeri di Kota Bandung dengan kategori kuat.

Kata kunci: kemampuan kerja, motivasi berprestasi, kinerja

\section{PENDAHULUAN}

Layanan administrasi yang berkualitas memegang peranan penting dan menentukan berbagai aspek yang menyangkut kegiatan dalam organisasi. Setiap aktivitas dicatat dan dihimpun secara cermat dan teratur sebagai data dan informasi yang diperlukan untuk perbaikan dan pengembangan organisasi. Kemudahan, kecepatan, dan ketepatan dalam layanan administrasi akan mempengaruhi efektivitas institusi.

Karena itu, Tenaga Administrasi Sekolah 
perlu memiliki kemampuan administrasi yang baik. Kemampuan administrasi tersebut berkaitan dengan kegiatan pencatatan terhadap segala sesuatu yang terjadi di sekolah untuk digunakan sebagai bahan keterangan dan pengambilan keputusan bagi pimpinan dan stakeholder. Mereka berperan dalam melancarkan kehidupan dan perkembangan organisasi secara fungsional. Mereka beperan sebagai pusat informasi dan sumber dokumen untuk memperlancar kehidupan dan perkembangan sekolah dalam keseluruhan sistem.

Kemampuan administrasi Tenaga Administrasi Sekolah dalam hal ini Kepala Tata Usaha diperlukan untuk melaksanakan tugas dan fungsinya. Sebagaimana dijelaskan dalam Keputusan Dirjen Dikdasmen No. 260 dan 261 Tahun 1996, Kepala Tata Usaha Sekolah mempunyai tugas pokok melaksanakan ketatausahaan sekolah dan bertanggung jawab kepada Kepala Sekolah dalam kegiatan-kegiatan sebagai berikut: (1) Penyusunan program kerja tata usaha sekolah; (2) Pengelolaan keuangan sekolah; (3) Pengurusan administrasi ketenagaan dan siswa;(4)Pembinaan dan pengembangan karir pegawai serta tata usaha sekolah; (5) Penyusunan administrasi perlengkapan sekolah; (6) Penyusunan dan penyajian data/ statistik sekolah; (7) Mengkoordinasikan dan melaksanakan 7K; dan (8) Penyusunan laporan pelaksanaan kegiatan pengurusan ketatausahaan secara berkala.

Untuk melaksanakan tugas pokok di atas selain faktor kemampuan kerja, juga diperlukan motivasi berprestasi. Motivasi berprestasi merupakan dorongan atau spirit bagi Kepala Tata Usaha untuk melakukan tugas dan fungsinya dengan baik. Dorongan tersebut bisa datang dari dalam dirinya maupun dari luar dirinya. Dorongan dari dalam dirinya merupakan faktor yang paling baik dan berjalan secara alamiah. Faktor-faktor tersebut berkaitan dengan atitude dan apttude, yakni pengetahuan dan pengalaman serta sikap dan perilaku sebagai cerminan citra diri. Bagi seseorang yang memiliki citra diri tinggi ia akan bersemangat untuk menunjukkan hasil kerja yang memuaskan para pelanggannya. Sedangkan bagi seseorang yang memiliki kebutuhan akan cinta dan kasih sayang ia akan memperlakukan peserta didik dengan lembut seperti anak sendiri dan hormat pada atasan, serta melakukan pekerjaan dengan menyenangkan. Sedangkan faktor dari luar menyangkut lingkungan kerja dan lingkungan kehidupan pribadinya. Lingkungan kerja yang kondusif akan mendorong Kepala Tata Usaha bekerja dengan tenang. Mereka akan terdorong untuk meningkatkan diri dengan ikhlas, melaksanakan tugas dan fungsinya dengan sungguh-sungguh, melahirkan ide, gagasan yang segar, kreatif dan inovatif.

Hasil wawancara dengan AKTAS (Asosiasi Kepala Tata Usaha SMP, SMA dan SMK) Negeri Kota Bandung dan beberapa orang Kepala Sekolah SMP Negeri di Kota Bandung mengatakan bahwa pendidikan dan pelatihan Administrasi Umum (Diklat ADUM) serta pendidikan dan pelatihan Kepemimpinan (Diklat PIM) bagi Kepala Tata Usaha SMP di kota Bandung belum berdampak secara signifikan pada peningkatan mutu pendidikan. Hal ini terlihat dari beberapa indikator yang menunjukkan bahwa mutu dan kinerja pegawai tata usaha sekolah termasuk kinerja kepala tata usaha sekolah masih rendah. Selain itu, beberapa permasalahan dapat diidentifikasi sebagai berikut:

1. Kinerja Kepala Tata Usaha belum optimal, hal itu ditunjukkan dengan kurangnya kesadaran akan upaya untuk mempersiapkan rencana program kegiatan jangka panjang dan jangka pendek dengan baik, tidak adanya penyusunan laporan berkala, analisis kebutuhan, tidak adanya motivasi dan semangat dalam mendorong keberhasilan pekerjaan yang berdampak langsung pada Proses Belajar Mengajar, dan kurangnya kesadaran untuk meningkatkan kompetensi diri. 
2. Kurangnya bimbingan, pengembangan, motivasi, dan kerjasama dari stakeholder dan Kepala Sekolah sebagai atasan langsung terhadap pelaksanaan kinerja Tenaga Administrasi Sekolah dan pengembangan kompetensi Kepala Tata Usaha, kurangnya motivasi kerja tersebut selain dipengaruhi oleh faktor internal dan eksternal.

3. Percaya diri dalam mengambil resiko adalah hal yang harus dimiliki oleh Kepala Tata Usaha. Mereka diduga kurang berani mengambil resiko dan kadang-kadang masih tergantung pada pandangan orang lain serta kurang berani mengambil keputusan dalam menjawab tantangan-tantangan dan memanfaatkan peluang-peluang yang ada, sehingga ide dan gagasan dalam memajukan sekolah yang sebenarnya ada pada diri mereka tidak terungkapkan.

4. Kurang komptennya Kepala Tata Usaha melaksanakan pekerjaannya karena latar belakang pendidikan yang kurang sesuai untuk jabatan tersebut.

5. Sarana dan prasarana yang kurang baik bagi pelaksanaan pekerjaan Kepala Tata Usaha.

6. Kepala Tata Usaha kurang memahami Teknologi Informasi dan Komunikasi (TIK).

Paparan di atas mendorong penulis untuk melakukan penelitian tentang kontribusi kemampuan kerja dan motivasi berprestasi terhadap kinerja Kepala Tata Usaha Sekolah Menengah Pertama Negeri di Kota Bandung. Secara umum penelitian ini ingin memperoleh gambaran nyata mengenai kontribusi kemampuan kerja dan motivasi berprestasi terhadap kinerja Kepala Tata Usaha SMP dengan asumsi apabila Kepala Tata Usaha memiliki kinerja tinggi akan berdampak pada layanan administrasi yang baik dan berkualitas. Secara tidak langsung akan menciptakan lulusan yang berkualitas dan produktif sebagai salah satu cermin peningkatan mutu pendidikan di sekolah.

\section{METODE PENELITIAN}

Permasalahan dalam penelitian ini adalah bagaimana memperbaiki dan meningkatkan kemampuan kerja dam motivasi berprestasi Kepala Tata Usaha SMP Negeri di Kota Bandung. Untuk itu, penelitian ini menggunakan metode kuantitatif, sedangkan pengolahan data menggunakan bantuan statistik. Data diperoleh melalui angket yang disebarkan kepada 30 orang Kepala Sekolah sebagai data primer dan 30 orang Kepala Tata Usaha sebagai data sekunder.

Data primer digunakan sebagai data utama yang diolah setelah melalui uji homogenitas. Sedangkan data skunder digunakan sebagai data pendukung untuk menguatkan hasil pengolahan data primer. Analisis data menggunakan teknik korelasional dan regresi dengan menggunakan statistik parametrik.

\section{HASIL DAN PEMBAHASAN PENELITIAN \\ 1. Hasil Penelitian \\ a. Deskripsi Variabel Penelitian}

Hasil perhitungan dengan menggunakan rumus WMS (Weighted Means Scored), dapat dilihat pada tabel berikut ini.

Tabel 1.1

Kecenderungan Variabel Penelitian

\begin{tabular}{lcc}
\hline \multicolumn{1}{c}{ Variabel } & Skor WMS & Kategori \\
\hline $\begin{array}{l}\text { Variabel X1 } \\
\text { Kemampuan Kerja Kepala Tata Usaha }\end{array}$ & 3,43 & Tinggi \\
\hline $\begin{array}{l}\text { Variabel X2 } \\
\text { Motivasi Berprestasi Kepala Tata Usaha }\end{array}$ & 3,45 & Tinggi \\
$\begin{array}{l}\text { Variabel Y } \\
\text { Kinerja Kepala Tata Usaha }\end{array}$ & 3,30 & \\
\hline
\end{tabular}


b. Hasil Pengujian Persyaratan Analisis Data

Hasil uji normalitas data dengan menggunakan Chi Kuadrat dapat dilihat pada tabel berikut ini.

Tabel 1.2

Hasil Uji Normalitas Menggunakan Chi Kuadrat

\begin{tabular}{llll}
\hline Variabel & $\chi^{2}$ hitung & $\chi^{2}$ tabel & Keterangan \\
\hline $\begin{array}{l}\text { Kemampuan Kerja } \\
\text { Tata Usaha (X1) }\end{array}$ & 7,89 & 12,60 & $\begin{array}{l}\text { Berdistribusi } \\
\text { Normal }\end{array}$ \\
\hline $\begin{array}{l}\text { Motivasi Berprestasi Kepala } \\
\text { Tata Usaha (X2) }\end{array}$ & 8,40 & 12,60 & $\begin{array}{l}\text { Berdistribusi } \\
\text { Normal }\end{array}$ \\
\hline $\begin{array}{l}\text { Kinerja Kepala Tata Usaha (Y) } \\
\text { 12,36 }\end{array}$ & 12,60 & $\begin{array}{l}\text { Berdistribusi } \\
\text { Normal }\end{array}$ \\
\hline
\end{tabular}

Catatan: Taraf signifikansi 95\%

Tabel di atas, semua varaiabel korelasi untuk mengungkapkan derajat menunjukkan bahwa skor $\chi_{\text {hitung }}^{2}$ lebih besar dari $\chi_{\text {tabel }}^{2}$. Berdasarkan kriteria $\chi_{\text {hitung }}^{2}<$ $\chi_{\text {tabel}}^{2}$, dapat dikatakan bahwa semua variabel berdistribusi normal pada taraf signifikansi $95 \%$. hubungan antara variabel independen dan variabel dependen. Kuat lemahnya hubungan ditunjukkan oleh nilai Pearson Correlation (R). Hasil uji korelasi disajikan di bawah ini.

\section{c. Hasil Pengujian Hipotesis}

Pengujian hipotesis menggunakan analisis

Tabel 1.3

Hasil Uji Korelasi

\begin{tabular}{|c|c|c|c|c|}
\hline Hipotesis & $\mathrm{R}_{\text {hitung }}$ & $\mathrm{R}_{\text {tabel }}$ & $\mathrm{dk}$ & Keterangan \\
\hline Kontribusi variabel X1 terhadap Y & 0,76 & 0,36 & 30 & Signifikan \\
\hline \multirow[t]{2}{*}{ Kontribusi variabel $\mathrm{X} 2$ terhadap $\mathrm{Y}$} & 0,69 & 0,34 & 30 & Signifikan \\
\hline & $F_{\text {hitung }}$ & $\mathrm{F}_{\text {tabel }}$ & $\mathrm{dk}$ & \\
\hline $\begin{array}{l}\text { Kontribusi variabel X1 dan X2 terhadap } \\
\text { Y }\end{array}$ & 19,70 & 3,35 & $\begin{array}{l}\mathrm{Py}: 2 \\
\mathrm{~Pb}: 27\end{array}$ & Signifikan \\
\hline
\end{tabular}

Tabel di atas menunjukkan bahwa semua hipotesis yang diajukan diterima, artinya terdapat kontribusi antara variabel yang dikomparasikan.

\section{d. Hasil Pengujian Regresi}

Uji regresi dilakukan dengan uji regresi sederhana dan uji regresi ganda. Hasil pengujian dapat dilihat pada tabel berikut ini.

Tabel 1.4

Hasil Uji Regresi

\begin{tabular}{lll}
\hline Kontribusi antar Variabel & Persamaan Regresi & Keterangan \\
\hline Kontribusi variabel X1 terhadap $Y$ & $\mathrm{Y}=9,08+1,01 \mathrm{X}_{1}$ & Regresi Sederhana \\
\hline Kontribusi variabel X2 terhadap $\mathrm{Y}$ & $\mathrm{Y}=16,25+1,02 \mathrm{X}_{2}$ & Regresi Sederhana \\
\hline $\begin{array}{l}\text { Kontribusi variabel X1 dan X2 } \\
\text { terhadap Y }\end{array}$ & $\mathrm{Y}=8,99+0,49 \mathrm{X}_{1}+0,34 \mathrm{X}_{2}$ & Regresi Ganda \\
\hline
\end{tabular}




\section{Pembahasan Penelitian}

a. Kemampuan Kerja Kepala Tata Usaha SMP Negeri di Kota Bandung

Kemampuan kerja adalah sifat (bawaan atau dipelajari) yang memungkinkan seseorang melakukan sesuatu yang bersifat mental atau fisik (Gibson at.al; 2012:127). Sifat bawaan berkaitan dengan karakter seseorang yang secara alami ditunjukkannya dalam merespon setiap tugas yang diberikan kepadanya. Sifat bawaan ini tumbuh dan berkembang seiring dengan perkembangan individu. Unsur-unsur dominan yang mempengaruhi sifat ini biasanya dialami sejak kecil misalnya pola asuh, lingkungan keluarga, lingkungan sosial, dan budaya. Sedangkan sifat yang dipelajari merupakan hasil dari belajar baik pada jenjang persekolahan maupun luar sekolah. Khusus untuk keahlian tertentu dirancang dan disiapkan untuk pengembangan profesi misalnya keterampilan khusus ketatausahaan, manajemen kearsipan, admnistrasi persuratan, dan keahlian profesi lainnya.

Hasil penelitian dari responden Kepala Sekolah menunjukkan kemampuan kerja baik secara fisik maupun mental Kepala Tata Usaha berada pada kategori tinggi yakni berada pada skor rata-rata 3,43 sedikit lebih rendah dibandingkan hasil penelitian dari responden Kepala Tata Usaha (3,52). Artinya dari indikator-indikator kemampuan kerja yang diteliti berpengaruh terhadap peningkatan kemampuan kerja. Kecenderungan tersebut menurut hasil penelitian digambarkan pada bagan berikut ini.

Gambar 1.1

Kecenderungan Kemampuan Kerja Kepala Tata Usaha

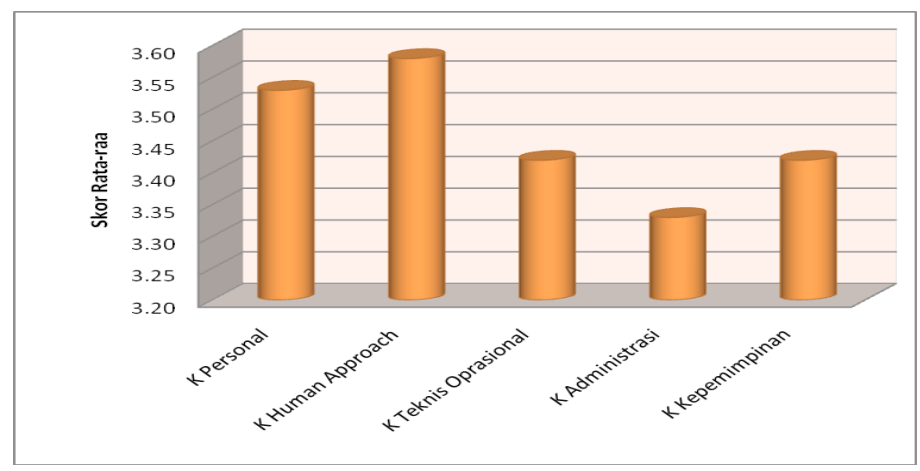

Gambar di atas menunjukkan bahwa kemampuan human approach memiliki skor tertinggi. Artinya Kepala Tata Usaha Sekolah SMP Negeri di Kota Bandung rata-rata memiliki kemampuan kerja dalam pendekatan kemanusiaan. Berkaitan dengan hal ini Kepala Tata Usaha Sekolah SMP Negeri di Kota Bandung memiliki kemampuan dalam hal membangun kerjasama dalam tim, mampu memberikan layanan yang baik, komunikatif, dan menumbuhkan hubungan kerja yang sehat baik dengan atasan, teman sejawat maupun dengan instansi terkait lainnya. Hal ini diduga berkaitan dengan kualifikasi pendidikan dan masa kerja Kepala Tata Usaha. Sejalan dengan hal tersebut
Robbins (1998) mengungungkapkan bahwa kemampuan kerja seseorang dipenaruhi oleh tiga faktor yaitu kesanggupan kerja, pendidikan, dan masa kerja.

Indikator tertinggi kedua adalah kemampuan personality, yakni kemampuan individu berkaitan dengan sikap mental dan karakter Kepala Tata Usaha. Kemampuan tersebut ditunjukkan dengan dimilikinya integritas dan akhlak yang baik, menunjukkan ethos kerja yang tinggi, kreatif dan inovatif, serta memiliki rasa tanggung jawab terhadap hail kerja.

Kemampuan kepemimpinan dan kemampuan teknis operasional bearada pada kategori tinggi walaupun masih di 
bawah kemampuan humman approach dan kemampuan personality. Kemampuan kepemimpinan Kepala Tata Usaha Sekolah SMP Negeri di Kota Bandung rata-rata menunjukkan kemampuannya dengan baik dalam hal pengambilan keputusan, menciptakan iklim kerja yang kondusif, dapat memanfaatkan sumber daya dengan efektif, dan mampu membina staf dengan baik.

Sedangkan kemampuan teknis operasional ditunjukkan dalam hal penyusunan rencana dan program kerja, penyusunan laporan, analisis kebutuhan, penggunaan dan penerapan Teknologi Informasi dan Komunikasi (TIK) seperti penggunaan komputer, LCD, proyektor, aplikasi program, jaringan, dan internet. Rata-rata mereka masih perlu ditingkatkan kemampuannya apalagi perkembangan TIK berjalan cepat dan mempengaruhi setiap sendi kehidupan termasuk pekerjaan layanan administrasi di sekolah.

Kemampuan administrasi menunjukkan kategori yang paling lemah dibandingkan indikator lain. Kemampuan adminitrasi yang perlu ditingkatkan adalah administrasi kepegawaian, keuangan, sarana dan prasarana, hubungan sekolah dengan masyarakat, persuratan dan pengarsipan, kurikulum, dan administrasi layanan khusus.

Dengan demikian perlu ada usaha untuk mengembangkan kemampuan Kepala Tata Usaha Sekolah khususnya dalam kemampuan teknis operasional dan kemampuan administrasi. Kemampuan tersebut bukan saja karena tuntutan perkembangan zaman tetapi juga merupakan tantangan bagi pertumbuhan dan perkembangan efektivitas sekolah. Menurut Soeroto (1992) untuk meningkatkan kemampuan kerja ada tiga komponen meliputi: (1) Upaya mengembangkan dan memelihara pertumbuhan rohani dan jasmani serta usaha menjaga kesehatan. Jika seseorang memiliki pertumbuhan fisik dan psikis yang kuat maka ia akan memiliki potensi dan peluang yang besar untuk ditumbuhkan dan dikembangkan kemampuan kerjanya; (2) Upaya bukan hanya terbatas pada kemampuan ratio dan fisik untuk memecahkan masalah-masalah yang dihadapi dalam jangka pendek, akan tetap mencakup ketahanan, keuletan fisik dan mental dalam mengatasi berbagai kesulitan dan tekanan dalam pekerjaan sehingga selesai dan mencapai hasil; (3) Upaya agar seseorang dapat dipekerjakan agar setiap organisasi yang memiliki kemampuan dimanfaatkan untuk memberikan kesejahteraan kepada masyarakat.

Upaya peningkatan kemampuan kerja Kepala Tata Usaha Sekolah tidak terbatas pada peningkat kemampuan administrasi dan teknis operasional saja, tetapi perlu didukung dengan upaya pertumbuhan organisasi yang sehat. Sekolah yang efektif dengan sendirinya akan mendorong Kepala Tata Usaha Sekolah secara sadar tanpa harus dipaksa untuk mengembangkan diri. Kepala Tata Usaha Sekolah dengan kemampuan kerja yang baik akan mendorong pencapaian tujuan sekolah dengan efektif dan efisien. Sebaliknya organisasi sekolah yang sehat dengan sendirinya akan menumbuhkan kemampuan kerja yang maksimal.

\section{b. Motivasi Berprestasi Kepala Tata Usaha SMP Negeri di Kota Bandung}

Motivasi terbentuk dari sikap (attitude) karyawan dalam menghadapi situasi kerja di perusahaan (situation) (Mangkunegara; 2008:61). Motivasi merupakan kondisi atau energi yang menggerakkan diri Kepala Tata Usaha yang terarah atau tertuju untuk mencapai tujuan sekolah. Sikap berkaitan dengan pendorong dalam diri Kepala Tata Usaha untuk berusaha dan bekerja dengan sungguh-sungguh semata-mata untuk kemajuan sekolah. Sedangkan situasi berkenaan dengan dorongan dari luar atau lingkungan sekitarnya sehingga ia tergerak untuk melakukan usaha. Jadi motivasi dipengaruhi oleh dua faktor, yakni dari dalam dan dari luar.

Hasil penelitian menurut responden 
Kepala Sekolah menunjukkan bahwa motivasi berprestasi Kepala Tata Usaha SMP Negeri di Kota Bandung termasuk dalam kategori tinggi dengan skor ratarata 3,34 sedikit lebih rendah menurut responden Kepala Tata Usaha (3.62). Artinya motivasi berprestasi mereka sangat baik yang diukur dari indikator tanggung jawab

Gambar 1.2

Kecenderungan Motivasi Berprestasi Kepala Tata Usaha

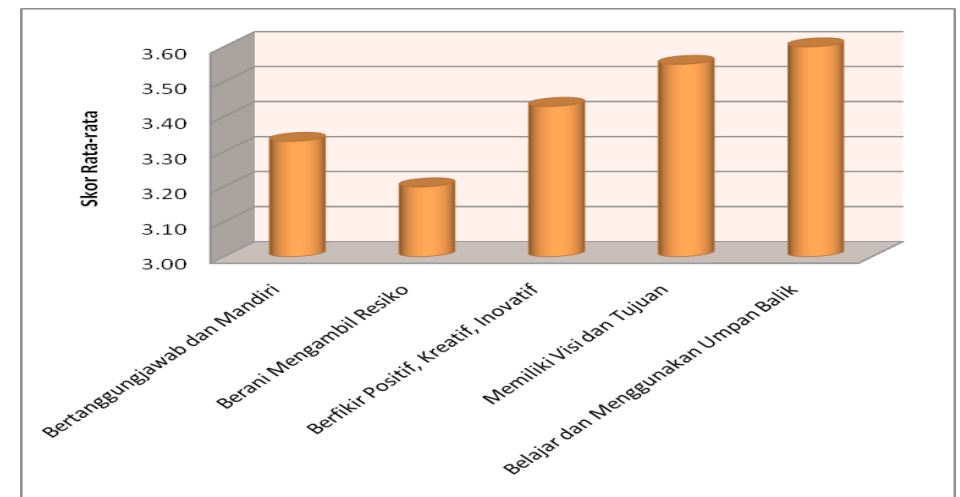

Gambar di atas menunjukkan bahwa kecenderungan motivasi berprestasi Kepala Tata Usaha Sekolah tinggi. Artinya mereka memiliki dorongan yang kuat baik dari dalam dirinya maupun dari luar untuk melaksanakan tugas dan fungsi kerja sehari-hari. Indikator tertinggi adalah dimilikinya visi dan tujuan, serta keinginan untuk selalu belajar dan mengunakan umpan balik.

Berkaitan dengan hal tersebut, McClelland yang dikutip Mangkunegara (2005:68) berpendapat bahwa seseorang yang visioner akan memiliki gambaran atau bayangan akan masa depan yang hendak dicapai. Hasil penelitian menunjukkan bahwa Kepala Tata Usaha Sekolah dapat melaksanakan tugas sesuai denga rencana. Mereka berusaha keras untuk mewujudkan tujuan dan keberhasilan sekolah dalam sesuai dengan standar kualitas yang ditetapkan. Mereka rata-rata mengerjakan tugas dengan tekun, selalu meningkatkan kemampuan diri, konsisten dan fokus terhadap tugas. Mereka memiliki strategi dan cara-cara yang efektif untuk meraih tujuan yang telah ditetapkan. Mereka juga mampu merumuskan tujuan jangka panjang, menengah, maupun jangka dan kemandirian dalam bekerja, berani mengambil resiko dan percaya diri, semangat kerja, prakarsa, tanggung jawab terhadap tugas, dan pencapaian target. Kecenderungan motivasi berprestasi Kepala Tata Usaha SMP Negeri di Kota Bandung dapat dilihat pada grafik di bawah ini. pendek. Ia senantiasa melakukan evaluasi dan penyesuaian-penyesuaian tujuan yang telah dirumuskan untuk memastikan tujuan tersebut konsisten dengan visi pribadi yang berkembang.

Kepala Tata Usaha Sekolah selalu melakukan introspeksi dan memperbaiki kelemahan dan kegagalan dalam melaksanakan tugas. Mereka tidak menyalahkan orang lain jika gagal tetapi berusaha menghargai dan belajar atas kegagalan tersebut. Mereka menghargai atas hasil usaha stafnya dengan terus memberikan bimbingan dan pendekatan untuk meningkatkan keberhasilan tugas berikutnya. Hal ini sejalan dengan pendapat Mangkunegara (2008) yang menyatakan bahwa seseorang yang memiliki motivasi berprestasi akan senang mempelajari apa saja yang menyebabkan dirinya gagal dan berhasil dari waktu ke waktu dan hasil pembelajarannya akan digunakan untuk menyempurnakan usaha selanjutnya.

Indikator tanggung jawab, mandiri, berpikir positif, kreatif, dan inovatif merupakan faktor pendorong yang kuat, meskipun masih di bawah indikator yang 
dipaparkan di atas. Tanggung jawab artinya Kepala Tata Usaha Sekolah selalu bertanggung jawab pada usahanya, apapun dampak yang timbul dari usahanya tersebut. Mereka tidak menyalahkan faktor lain dari luar dirinya, tetapi berintrospeksi dan mempertanggungjawabkan hasil pekerjaannya tersebut. Umumnya mereka sabar, tidak mudah menyerah, tidak mudah marah bila dikritik, dan bersikap wajar jika dipuji. Mereka selalu mencoba sesuatu yang baru meskipun telah gagal dan selalu mencari jalan keluar atas kegagalan tersebut. Mereka juga mampu mengorganisir pekerjaannya sehingga tugas yang diberikan dapat disederhanakan tetapi memperoleh hasil yang maksimal.

Indikator motivasi berprestasi yang masih lemah pada diri Kepala Tata Usaha Sekolah adalah berani mengambil resiko dan percaya diri. Mereka kurang berani mengambil resiko dan kadang-kadang masih tergantung pada pandangan orang lain. Mereka kurang berani mengambil keputusan dalam menjawab tantangan dan memanfaatkan peluang yang ada. Umumnya mereka kurang percaya diri atas kemampuan dirinya, sehingga masih terombang-ambing pada situasi yang menghimpitnya. Kurangnya percaya diri juga mengakibatkan mereka kurang kritis dalam mengungkapkan ide dan gagasannya. Padahal kalau mereka berani, ide dan gagasannya dapat memajukan keberhasilan sekolah.

\section{c. Kinerja Kepala Tata Usaha SMP Negeri di Kota Bandung}

Kinerja Kepala Tata Usaha Sekolah adalah hasil kerja yang terukur sesuai dengan standar dan kriteria yang ditetapkan. Sedangkan penampilan prilaku kerja mereka ditandai oleh keluwesan gerak, ritme dan urutan kerja yang sesuai dengan prosedur sehingga diperoleh hasil yang memenuhi syarat kualitas, kecepatan dan jumlah yang direncanakan.

Hasil penelitian menurut responden Kepala Sekolah menunjukan kecenderungan kinerja Kepala Tata Usaha SMP Negeri di Kota Bandung termasuk kategori tinggi dengan skor rata-rata 3,38 sedikit lebih rendah menurut responden Kepala Tata Usaha $(3,40)$. Artinya mereka memiliki kinerja yang termasuk kategori tinggi dengan indikator loyalitas kerja, semangat kerja, prakarsa, tanggung jawab, dan pencapaian target. Kecenderungan kinerja Kepala Tata Usaha SMP Negeri dikota Bandung dapat dilihat pada gambar berikut ini.

\section{Gambar 1.3}

Kecenderungan Kinerja Kepala Tata Usaha

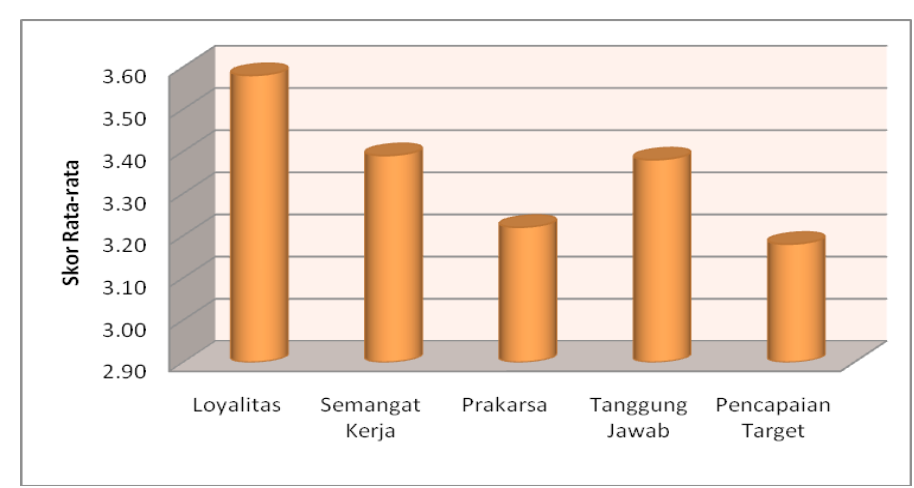

Gambar di atas menunjukkan indikator tertinggi ditunjukkan oleh indikator loyalitas, artinya Kepala Tata Usaha Sekolah memiliki loyalitas sangat tinggi dalam melaksanakan pekerjaan. Mereka fokus pada tugas yang diberikan kepadanya, mengutamakan pelanggan, berkomunikasi dengan baik, dan disiplin dalam bekerja. Mereka juga aktif dalam berbagai kegiatan sekolah dan berusaha keras untuk mewujudkan tujuan sekolah sampai berhasil.

Indikator semangat kerja dan tanggung 
jawab berada pada kategori di bawah loyalitas, meskipun masih tergolong tinggi. Semangat kerja mereka tunjukkan dari kesungguhannya dalam melaksanakan tugas dan pekerjaan sehari-hari. Mereka juga dapat menyelesaikan tugas tepat waktu dan berusaha mengembangkan diri untuk meningkatkan kualitas kerja. Dalam bekerja mereka melaksanakan tugas sesuai dengan aturan dan pedoman yang berlaku. Mereka juga tidak melimpahkan kesalahan pada orang lain, tanggung jawab atas hasil kerja dan perbuatannya.

Dalam hal prakarsa masih termasuk kategori tinggi berada di bawah loyalitas, semangat, dan tanggung jawab dalam penyelesaian pekerjaan. Mereka masih lemah dalam menyampaikan ide dan gagasan untuk efektivitas dan efisiensi pekerjaan. Mereka lebih senang mengikuti perintah dan aturan yang ada sehingga kurang menunjukkan inovasi dan kreatifitas dalam bekerja. Hal ini dimungkinkan oleh keterbatasan kewenangan mereka di bandingkan dengan Kepala Sekolah atau jabatan tenaga kependidikan lainnya.

Indikator paling lemah adalah pencapaian target. Kepala Tata Usaha masih lemah dalam menentukan sasaran kerja dan strategi pencapaiannya baik jangka pendek maupun jangka panjang. Mereka masih lemah dalam menganalisis kebutuhan yang diperlukan dalam pekerjaan. Mereka juga kurang mampu dalam mengefektifkan sumber daya yang dimiliki karena keterbatasan kewenangan dan kekuasaan dalam mengelola sumber daya. Akurasi dan ketepatan dalam menyelesaikan pekerjaan masih perlu dikembangkan lagi sehingga efektifitas hasil kerja perlu ditingkatkan sampai menujukkan hasil kerja yang maksimal.

\section{d. Kontribusi Kemampuan Kerja Terhadap Kinerja Kepala Tata Usaha SMP Negeri di Kota Bandung}

Hasil uji korelasi antara kemampuan kerja (X1) terhadap kinerja Kepala Tata Usaha (Y) sebesar 0,76 jika dibandingkan dengan nilai $\mathrm{r}_{\text {tabel }}$ sebesar 0,36 maka ditemukan $\mathrm{r}_{\text {hitung }}>$ $r_{\text {tabel }}(0,76>0,36)$. Hal ini berarti terdapat kontribusi antara variabel X1 terhadap variabel Y. Hasil perhitungan terhadap responden Kepala Tata Usaha menunjukkan hal yang sama yakni $r_{\text {hitung }}>r_{\text {tabel }}(0,47>0,40)$. Sedangkan hasil uji signifikansi ditemukan nilai $t_{\text {hitung }}$ sebesar $=6,30$ sementara $t_{\text {tabel }}$ sebesar 1,70 maka ditemukan persamaan $\mathrm{t}_{\text {hitung }}$ $>t_{\text {tabel }}(6,30>1,70)$. Hal ini berarti kontribusi variabel $\mathrm{X} 1$ terhadap $\mathrm{Y}$ adalah signifikan. Koefisien korelasi sebesar 0,76 termasuk pada kategori kuat. Hasil uji regresi diperoleh nilai persamaan regresi linier sederhana $\mathrm{Y}=$ $9,08+1,01 \mathrm{x}_{1}$. Merujuk pada hasil penelitian tersebut, dapat disimpulkan bahwa terdapat kontribusi yang signifikan dan kuat antara kemampuan kerja terhadap kinerja Kepala Tata Usaha SMP Negeri di Kota Bandung.

Hasil penelitian di atas, mendorong sekolah untuk meningkatkan kemampuan kerja yang dimiliki oleh Kepala Tata Usaha. Semakin tinggi tingkat kemampuan kerja mereka, maka kinerja di sekolah akan tinggi pula (Robbins,2003). Indikator potensial kemampuan kerja yang berkontribusi terhadap kinerja Kepala Tata Usaha dalam penelitian ini adalah: (1) Kemampuan individu; (2) Kemampuan kerja sama dalam tim; dan (3) Kemampuan kepemimpinan

Kemampuan individu Kepala Tata Usaha Sekolah dipengaruhi oleh pengalaman kerja dan kualifikasi pendidikan. Pengalaman kerja mereka rata-rata di atas 10 tahun yang menggeluti bidang yang sama, dengan demikian dimungkinkan mereka sudah mengerti bahkan memahami pekerjaan dan tugas pokoknya. Tingkat pendidikan mereka rata-rata berkualifikasi pendidikan $\mathrm{S} 1$, hal ini sesuai dengan standar pemerintah. Dengan kualifikasi pendidikan yang sudah bergelar sarjana mereka lebih percaya diri, dan mudah belajar untuk menguasi pekerjaannya. Jadi dengan kemampuan individu yang baik berkontribusi terhadap kinerja atau hasil kerja yang diharapkan.

Kemampuan kerjasama dalam tim 
merupakan kemampuan yang dimiliki dengan baik oleh Kepala Tata Usaha Sekolah. Hal ini dimungkinkan karena mereka berada dalam lingkungan sejawat yang berlangsung lama. Mereka juga menjalin komunikasi yang baik dan saling pengertian antarstaf. Mereka sering kerja bersama, saling mengingatkan dan mengetahui kemampuan dan kesanggupan masing-masing staf. Sehingga mereka mampu berkolaborasi dalam tim. Hal ini berkontribusi secara potensial untuk efektifitas pencapaian hasil kerja. Dengan kata lain satu pekerjaan jika dikerjakan secara tim akan menghasilkan pekerjaan yang berkualitas dengan kecepatan dan keakuratan yang dapat diandalkan.

Kemampuan kepemimpinan berkaitan dengan jabatannya. Kepala Tata Usaha Sekolah adalah orang-orang yang terpilih dari seleksi, secara otomatis mereka memiliki kemampuan kepemimpinan yang tidak diragukan lagi. Kemampuan kepemimpinan mereka gunakan untuk mendorong dan mempengaruhi berbagai sumber daya untuk keberhasilan pencapaian tujuan. Dengan demikian kemampuan kepemimpinan Kepala Tata Usaha Sekolah berkontribusi secara potensial terhadap kinerja mereka.

\section{e. Kontribusi Motivasi Berprestasi Terhadap Kinerja Kepala Tata Usaha SMP Negeri di Kota Bandung}

Hasil uji korelasi antara motivasi berprestasi (X2) terhadap kinerja Kepala Tata Usaha (Y) sebesar 0,69 jika dibandingkan dengan nilai $r_{\text {tabel }}$ sebesar 0,36 maka ditemukan $\mathrm{r}_{\text {hitung }} \stackrel{\text { tabel }}{>} \mathrm{r}_{\text {tabel }}(0,69>0,36)$. Hal ini berarti terdapat kontribusi antara variabel X2 terhadap variabel Y. Hasil perhitungan terhadap responden Kepala Tata Usaha menunjukkan hal yang sama yakni $\mathrm{r}_{\text {hitung }}$ $>\mathrm{r}_{\text {tabel }}(0,45>0,40)$. Sedangkan hasil uji signifikansi ditemukan nilai $t_{\text {hitung }}$ sebesar $=4,99$ sementara $t_{\text {tabel }}$ sebesar 1,70 maka ditemukan persamaan $t_{\text {hitung }}>t_{\text {tabel }}(4,99>$ 1,70). Hal ini berarti kontribusi variabel X2 terhadap Y adalah signifikan. Koefisien korelasi sebesar 0,69 berdasarkan kriteria yang dikemukakan pada Bab III termasuk pada kategori kuat. Hasil uji regresi diperoleh nilai persamaan regresi linier sederhana $\mathrm{Y}=$ $16,25+1,02 x_{2}$. Merujuk pada hasil penelitian tersebut, dapat disimpulkan bahwa terdapat kontribusi yang signifikan dan kuat antara motivasi berprestasi terhadap kinerja Kepala Tata Usaha SMP Negeri di Kota Bandung.

Hasil penelitian di atas sejalan dengan pendapat yang dikemukakan Mangkunegara (2005) bahwa motif untuk berprestasi berkaitan dengan kesungguhan upaya yang dilakukan seseorang untuk mencapai hasil yang baik dan memuaskan. Motivasi berprestasi adalah suatu keinginan untuk mengatasi atau mengalahkan suatu tantangan untuk kemajuan atau pertumbuhan. Motif ini menyebabkan seseorang mencari alternatif yang lebih baik dalam melaksanakan tugas maupun memecahkan masalah dalam kehidupannya. Beberapa indikator potensial motivasi berprestasi yang berkontribusi terhadap kinerja Kepala Tata Usaha Sekolah dalam penelitiann ini antara lain: (1) Memiliki visi dan tujuan berkelanjutan; (2) Keinginan untuk tumbuh dan belajar; (3) Memiliki rasa tanggung jawab; dan (4) Memiliki konsep diri positif (positif thinking)

Visi dan tujuan berkelanjutan yang dimiliki Kepala Tata Usaha Sekolah merupakan arah bagi mereka dalam mengerjakan tugas. Dengan visi dan tujuan yang dimiliki, mereka akan bekerja fokus pada sasaran yang hendak dicapai. Mereka juga mampu menyusun strategi dan menganalisis berbagai tantangan dan peluang untuk meningkatkan hasil kerja. Dengan visi dan tujuan yang dimiliki Kepala Tata Usaha dapat menyusun rencana kerja dengan baik, mengorganisir dan menyederhanakan prosedur kerja dengan efektif, memanfaatkan sumber daya dengan efisien, dan membangkitkan semangat kerja tim ke arah tujuan yang hendak dicapai.

Keinginan untuk tumbuh dan belajar berpotensi kuat mendongkrak kinerja Kepala Tata Usaha Sekolah. Setiap pekerjaan selalu berkembang baik tuntutannya maupun 
tantangannya. Karena itu, perlu keterampilan dan cara-cara baru untuk menangani pekerjaan. Kepala Tata Usaha Sekolah yang memiliki keinginan untuk belajar akan cepat beradaptasi dengan pekerjaan baru. Mereka juga akan tergerak hatinya untuk menguasai dan memahami jenis pekerjaan yang menantang. Mereka akan belajar bagaimana mengatasi masalah dan menjadi solusi dalam menyelesaikan pekerjaan sehari-hari.

Tanggung jawab yang besar terhadap pekerjaan merupakan salah satu dorongan bagi Kepala Tata Usaha untuk bekerja lebih baik lagi. Mereka umumnya tidak menyalahkan orang lain, justru mereka belajar dan mengambil hikmah dari kesalah-kesalahan masa lalu. Dengan tanggungjawabnya mereka berorientasi pada hasil, tidak ingin mengecewakan pengguna jasa baik atasannya maupun instansi dan kelompok masyarakat lain pengguna pendidikan. Mereka akan sungguh-sungguh dalam menyelesaikan pekerjaan. Dengan demikian, stakeholders akan merasa puas terhadap layanan dan kinerja Kepala Tata Usaha Sekolah.

Kepala Tata Usaha Sekolah Umumnya memiliki konsep diri yang baik, berfikir postif, dan mampu mengendalikan diri. Hal ini dimungkinkan karena tingkat kedewasaan dan kematangan berfikir mereka. Dengan pengalaman kerja dan kebiasaan mereka bergaul dengan berbagai kalangan membawa mereka pada satu kondisi dimana konsep diri menjadi lebih kuat. Dengan berfikir positif mereka bekerja dengan tenang, sabar, tidak tergesa-gesa, tidak mudah marah, tidak mudah panik, dan profesional. Pekerjaan dikerjakan dengan tekun dan sungguhsungguh. Sehingga dengan konsep diri positif yang dimiliki Kepala Tata Usaha Sekolah akan menghasilkan kinerja yang dapat diandalkan.

\section{f. Kontribusi Kemampuan Kerja dan Motivasi Berprestasi Terhadap Kinerja Kepala Tata Usaha SMP Negeri di Kota Bandung}

Hasil uji korelasi ganda antara kemampuan kerja (X1 dan motivasi berprestasi (X2) secara simultan terhadap kinerja Kepala Tata Usaha (Y) sebesar 0,77 menurut Kepala Sekolah dan menurut responden Kepala Tata Usaha lebih rendah $(0,620$. Jika dibandingkan kriteria pengujian nilai koefisien korelasi tersebut termasuk kategori kuat. Sedangkan hasil uji signifikansi ditemukan nilai $\mathrm{F}_{\text {hitung }}$ sebesar $=19,70$ sementara $F_{\text {tabel }}$ sebesar 3,35 maka ditemukan persamaan $\mathrm{F}_{\text {hitung }}>\mathrm{F}_{\text {tabel }}(19,70$ $>3,435)$. Hal ini berarti kontribusi variabel X1X2 terhadap Y adalah signifikan. Hasil perhitungan terhadap responden Kepala Tata Usaha menunjukkan hal yang sama yakni $\mathrm{F}_{\text {hitung }}>\mathrm{F}_{\text {tabel }}(5,07>3,47)$.

Hasil uji regresi diperoleh nilai persamaan regresi linier berganda sebagai berikut:

$$
Y=8,99+0,49 x_{1}+0,34 x_{2} \text {. }
$$

Merujuk pada hasil penelitian tersebut, dapat disimpulkan bahwa terdapat kontribusi yang signifikan dan kuat antara kemampuan kerja dan motivasi berprestasi secara bersama-sama terhadap kinerja Kepala Tata Usaha SMP Negeri di Kota Bandung.

Hasil penelitian di atas sejalan dengan pandangan Stoner yang dikutip oleh Adiono (2002), mengemukakan bahwa prestasi individu disamping dipengaruhi oleh motivasi dan pengetahuan juga dipengaruhi oleh faktor persepsi peran yaitu pemahaman individu tentang perilaku apa yang diperlukan untuk mencapai prestasi individu. Kemampuan (ability) menunjukkan kemampuan seseorang untuk melakukan pekerjaan dan tugas. Sedangkan menurut Notoatmodjo (2002), bahwa faktor yang memengaruhi kinerja disingkat "ACHIEVE" yang artinya Ability (kemampuan pembawaan), Capacity (kemampuan yang dapat dikembangkan), Help (bantuan untuk terwujudnya kinerja), Incentive (insentif material maupun non material), Environment (lingkungan tempat 
kerja karyawan), Validity (pedoman/ petunjuk dan uraian kerja), dan Evaluation (adanya umpan balik hasil kerja).

Lebih spesifik menurut Davies (1989) bahwa faktor yang memengaruhi pencapaian kinerja adalah faktor kemampuan (ability) dan faktor motivasi (motivation). Faktor kemampuan secara psikologik terdiri dari kemampuan potensi (IQ) dan kemampuan reality, yang artinya Kepala Tata Usaha Sekolah yang memiliki IQ di atas ratarata dengan pendidikan yang memadai untuk jabatannya dan keterampilan dalam mengerjakan tugas sehari-hari maka ia akan lebih mudah mencapai kinerja yang diharapkan.

Pendapat Gibson (1987), secara teoritis ada tiga kelompok variabel yang memengaruhi perilaku kerja dan kinerja, yaitu: variabel individu, variabel organisasi dan variabel psikologis. Ketiga kelompok variabel tersebut memengaruhi kelompok kerja yang pada akhirnya memengaruhi kinerja personel. Perilaku yang berhubungan dengan kinerja adalah yang berkaitan dengan tugas-tugas pekerjaan yang harus diselesaikan untuk mencapai sasaran suatu jabatan atau tugas.

\section{SIMPULAN}

Kemampuan kerja Kepala Tata Usaha SMP Negeri di Kota Bandung berada pada kategori tinggi. Hal ini dapat dilihat dari semua indikator kemampuan kerja menunjukkan kategori tinggi. Indikator tersebut secara berurutan dari kategori tertinggi sampai kategori terendah meliputi: kemampuan human approach, kemampuan persoanality, kemampuan kepemimpinan, kemampuan teknis operasional, dan kemampuan administrasi.

a. Motivasi berprestasi Kepala SMP Negeri di Kota Bandung berada pada kategori tinggi. Semua indikator menunjukkan nilai rata-rata tinggi. Indikator dari skor yang paling tinggi ke skor rata-rata terendah meliputi: selalu belajar dan menggunakan umpan balik, memiliki visi dan tujuan, berfikir positif, kreatif, dan inovatif, bertanggung jawab dan mandiri, serta berani mengambil resiko dan percaya diri termasuk kategori cukup tinggi.

b. Kinerja Kepala Tata Usaha SMP Negeri di Kota Bandung berada pada kategori tinggi. Indikator tersebut meliputi: loyalitas, semangat kerja, dan tanggung jawab. Sedangkan indikator lain berada pada kategori cukup tinggi yakni indikator prakarsa dan pencapaian target.

c. Terdapat kontribusi positif dan signifikan antara kemampuan kerja terhadap kinerja Kepala Tata Usaha SMP Negeri di Kota Bandung. Besarnya kontribusi tersebut berada kategori kuat.

d. Terdapat kontribusi yang positif dan signifikan antara motivasi berprestasi terhadap kinerja Kepala Tata Usaha SMP Negeri di Kota Bandung. Besarnya kontribusi tersebut berada pada kategori kuat.

e. Terdapat kontribusi positif dan signifikan antara kemampuan kerja dan motivasi berprestasi terhadap kinerja Kepala Tata Usaha SMP Negeri di Kota Bandung. Besarnya kontribusi tersebut berada pada kategori kuat.

\section{DAFTAR RUJUKAN}

Arikunto, S. (2002). Prosedur Penelitian (Suatu Pendekatan Praktik). Bandung: Alfabeta.

Dirjen Dikdasmen No. 260 dan 261 Tahun 1996, Kepala Tata Usaha Sekolah.

Gibson, James L, et.al. (2012). Organizations : Behavior, Structure, Processes. 14 ${ }^{\text {th }}$ ed. Boston, Mass: McGraw-Hill/Irwin. Hoy, Wayne K \& Cecil G. Miskel. (2008). Education Administration: Theory, Research, and Practice. Singapure: Mc Graw-Hill Co. 
Mangkunegara, Anwar Prabu. 2008. Perilaku dan Budaya Organisasi. Bandung: Rafika Aditama.

Peraturan Menteri Pendidikan Nasional Repeublik Indonesia Nomor : 24 Tahun 2008 Tentang Standar Tenaga Administrasi Sekolah/Madrasah.

Robbins, Stephen P. (2003). Perilaku Organisasi, Buku 1 dan 2. Jakarta: PT. Indeks Kelompok Gramedia.

Soeroto, (2002), Strategi Pembangunan dan Perencanaan Kesempatan Kerja, Edisi 2, UGM Press, Yogyakarta.

Undang-Undang Nomor. 20 Tahun 2003 tentang Sistem Pendidikan Nasional.

Westra, Pariata, Dkk, (2003), Ensiklopedi Administrasi, Jakarta Gunung Agung. 